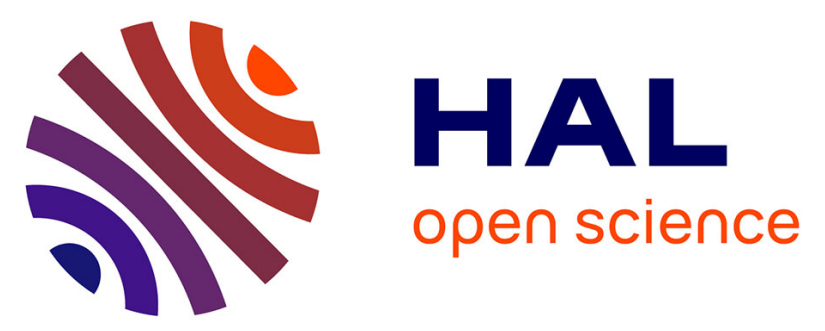

\title{
Recherche des sites d'expression de la tolérance vis-à-vis de Xanthomonas campestris pathovar manihotis (Arthaud-Berthet) Starr chez certains cultivars de manioc (Manihot esculenta Crantz)
}

\author{
Bernard Boher, Jean-François Daniel, Pierre Ndongo
}

\section{To cite this version:}

Bernard Boher, Jean-François Daniel, Pierre Ndongo. Recherche des sites d'expression de la tolérance vis-à-vis de Xanthomonas campestris pathovar manihotis (Arthaud-Berthet) Starr chez certains cultivars de manioc (Manihot esculenta Crantz). Agronomie, 1985, 5 (8), pp.677-683. hal-00884799

\author{
HAL Id: hal-00884799 \\ https://hal.science/hal-00884799
}

Submitted on 1 Jan 1985

HAL is a multi-disciplinary open access archive for the deposit and dissemination of scientific research documents, whether they are published or not. The documents may come from teaching and research institutions in France or abroad, or from public or private research centers.
L'archive ouverte pluridisciplinaire HAL, est destinée au dépôt et à la diffusion de documents scientifiques de niveau recherche, publiés ou non, émanant des établissements d'enseignement et de recherche français ou étrangers, des laboratoires publics ou privés. 


\section{Recherche des sites d'expression de la tolérance vis-à-vis de Xanthomonas campestris pathovar manihotis (Arthaud-Berthet) Starr chez certains cultivars de manioc (Manihot esculenta Crantz)}

Bernard BOHER \& Jean-François DANIEL

avec la participation technique de Pierre NDONGO

O.R.S.T.O.M., Laboratoire de Phytopathologie, Brazzaville, B.P. I81, Rep. Pop. du Congo

RÉSUMÉ Certains cultivars de manioc sont tolérants à la bactériose vasculaire. L'étude, après inoculation artificielle, du
comportement de ces cultivars et de cultivars vulnérables démontre l'existence de sites d'expression de la tolé-
rance à la maladie. Il s'agit de barrières anatomo-physiologiques susceptibles d'intervenir lors de l'infection
(élévation du seuil d'inoculum nécessaire, cicatrisation rapide des blessures sur le limbe) ou de la colonisation
des tissus de la plante (ralentissement de la migration du parasite dans les vaisseaux du xylème).
La vitesse de multiplication de la bactérie dans les espaces inter-cellulaires du mésophylle est comparable chez
les cultivars tolérants et sensibles.

Mots clés additionnels : Blessures, cicatrisation, multiplication inter-cellulaire, migration intravasculaire, seuil d'inoculum.

Additional key words : Wound, healing, intercellular multiplication, intravascular migration, inoculum threshold.

\section{INTRODUCTION}

Les observations faites pendant plusieurs années sur les collections de cultivars de manioc implantées par les services de la Recherche Agronomique de la République Populaire du Congo ont montré que certains d'entre eux étaient tolérants à la bactériose vasculaire (BOHER \& DANIEL, 1978).

Ces cultivars présentent des symptômes localisés au niveau foliaire (taches angulaires peu nombreuses). Dans les mêmes conditions les cultivars vulnẹ́rạhles montrent des lésions sur tige et des dessèchements de sommités.

Nous avons étudié le comportement de quelques cultivars vis-à-vis de Xanthomonas campestris pathovar manihotis (Arthaud-Berthet \& Bondar) Starr, agent de la bactériose vasculaire, à différents stades de l'infection et de la colonisation des tissus :

- infection au niveau de blessures sur le limbe,

- multiplication du parasite dans les espaces intercellulaires du limbe,

- invasion de la tige à partir de la feuille. 


\section{MATÉRIELS ET MÉTHODES}

Huit cultivars ont été sélectionnés pour mener nos expériences : "MA 147 », "MA 387 », « MA 446 », «MA 575 » et « Ngodiki » tolérants, « Mpembe», «Maloenda » et "Nkoh» vulnérables. Les 4 premiers sont originaires du Nigeria, les 4 suivants du Congo. Nous choisissons le terme de "vulnérable" de préférence à celui de "sensible » en nous référant au schéma de MUSSEL (1980).

L'étude de l'infection et de la vitesse de multiplication est faite sur des plants âgés de 2 mois des 8 cultivars, cultivés en pots (sol argilo-sableux de la région de Brazzaville) à partir de boutures.

Le limbe est blessé avant inoculation et ceci pour plusieurs raisons :

- le taux de réussite des contaminations par pulvérisation d'une suspension de bactéries même très dense $\left(10^{8}\right.$ à $10^{10}$ U.F.C. $\left./ \mathrm{ml}\right)$ sur une feuille de manioc non lésée est faible,

- l'infiltration totale du limbe par immersion dans une suspension de bactéries sous pression réduite est difficile voire même impossible avec de nombreux cultivars de manioc,

- dans la nature la blessure du limbe est une porte d'entrée préférentielle pour les parasites bactériens (DAFT \& LEBEN, 1972; CROSSE et al., 1972; PREECE, 1982).

Les blessures sont faites sur le limbe en découpant à l'emporte pièce des trous circulaires de $1,2 \mathrm{~mm}$ de diamètre à raison de 30 par foliole. Une goutte de $0,005 \mathrm{ml}$ de suspension bactérienne (souche 104.2 originaire de la région des Plateaux) est placée dans la lumière de la blessure et l'inoculation est répétée 3 à 5 fois sur des plants différents.

Cette suspension est obtenue à partir de cultures âgées de $48 \mathrm{~h}$ sur milieu L.P.G.A. (extrait de levure 5 p. 100 , peptone 5 p. 100 , glucose 5 p. 100 , agar 15 p. 100), qui subissent 3 lavages à l'eau stérile avant utilisation. L'incubation dure $7 \mathrm{j}\left(27^{\circ} \mathrm{C}, 85\right.$ p. 100 humidité) et la lecture est faite par observation à la loupe des bords de la blessure. L'inoculation est considérée comme réussie si on note l'apparition de taches angulaires translucides au contact de la partie blessée. Pour les témoins, on remplace la suspension bactérienne par de l'eau distillée stérile.

Pour étudier la multiplication du parasite dans les tissus, nous utilisons une technique d'inoculation associant blessure et infiltration. La suspension de bactéries $\left(10^{8}\right.$ U.F.C. $\left./ \mathrm{ml}\right)$ est inoculée avec un « Dermojet " de KRANTZ (1959) qui provoque la formation d'une petite blessure centrale avec un halo infiltré.

Les feuilles sont ensuite lavées (eau distillée + Tween 80 ) et leurs pétioles immergés dans une solution nutritive de SHIVE \& ROBBINS (in HEWITT, 1966).

Elles sont maintenues en humidité saturante à $25^{\circ} \mathrm{C}$ avec une périodicité lumineuse de $12 \mathrm{~h} / 12 \mathrm{~h}$. Immédiatement après inoculation et 24,48 et $72 \mathrm{~h}$ après, on prélève à l'emporte-pièce, pour chacune des 5 feuilles de l'expérience, 4 pastilles de $0,6 \mathrm{~cm}$ de diamètre autour du point d'inoculation sur 4 folioles différentes. Ces fragments de limbe sont lavés 3 fois (eau distillée stérile + Tween 80 ) sur un agitateur vibrant pour éliminer la microflore de surface puis broyés au mortier. On compte les colonies du parasite (U.F.C. = unités formant des colonies) qui se sont développées après étalement de dilutions de l'eau de broyage sur milieu L.P.G.A. et incubation à $30^{\circ} \mathrm{C}$ pendant $3 \mathrm{j}$. Dans quelques cas, nous avons réalisé une infiltration totale des tissus du limbe dans une suspension de bactéries $\left(10^{8}\right.$ U.F.C. $\left./ \mathrm{ml}\right)$ sous pression réduite. La foliole est ensuite maintenue en survie sur papier filtre humide à $27^{\circ} \mathrm{C}$ en atmosphère d'humidité saturante et l'analyse des populations du parasite faite comme précédemment.

Pour suivre le passage de l'agent pathogène de la feuille dans la tige, on utilise des plants âgés de 10 mois en plein champ. Des groupes de 5 feuilles de niveau 4 et plus âgées, attachées à un même rameau non aoûté, sont inoculés (nous donnons aux feuilles des numéros d'ordre, la feuille 2 est la $1^{\text {re }}$ feuille dont les folioles sont dépliées les feuilles 3, 4 etc. sont les feuilles suivantes par ordre d'âge croissant). Pour chacune des 5 feuilles l'inoculation est faite par infiltration à la seringue d'une suspension de bactéries de la souche 104-2 $\left(10^{8}\right.$ U.F.C. $\left./ \mathrm{ml}\right)$ en 2 points de part et d'autre de la nervure centrale et au tiers distal de la foliole médiane. Au fur et à mesure que les feuilles tombent, leur pétiole est prélevé, désinfecté par l'hypochlorite de calcium (solution à 2 p. 100) et découpé en 2 fragments égaux, distal et proximal, qui sont broyés dans l'eau stérile. La bactérie pathogène est mise en évidence par étalement de l'eau de broyage sur L.P.G.A. et incubation à $30^{\circ} \mathrm{C}$ pendant $3 \mathrm{j}$. Le pouvoir pathogène est vérifié par infiltration dans un limbe de cultivar sensible.

$\mathrm{Au}$ même moment des analyses du même type sont faites sur la cicatrice foliaire au niveau de la tige. Quand toutes les feuilles inoculées sont tombées, environ 2 mois et demi après l'inoculation, les tiges qui portaient ces feuilles sont découpées en morceaux de $7 \mathrm{~cm}$ sur une longueur de $50 \mathrm{~cm}$ que l'on traite comme les pétioles. Des tiges de plants non inoculés sont utilisées comme témoins.

\section{RÉSULTATS}

\section{A. Seuil d'inoculum au niveau de la blessure sur le limbe}

En faisant varier le nombre de cellules utilisées pour l'inoculation $\left(2.10^{1}\right.$ à $2.10^{10}$ U.F.C. par goutte déposée dans la lumière de la blessure), on note une différence dans le comportement de certains cultivars. La figure 1 donne les réactions observées chez 5 cultivars parmi les 8 précédemment cités. La quantité de bactéries nécessaire pour obtenir un taux de réussite supérieur à 0,9 est relativement faible pour 3 cultivars (« Mpembe », «MA 147 », « Ngodiki », environ $2.10^{3}$ U.F.C. $/ \mathrm{ml}$ ). Elle est 10 fois supérieure chez le cultivar "Maloenda » pour obtenir le même résultat. Enfin, le cultivar « MA 387 » semble le moins vulnérable car il faut une quantité 1000 fois plus élevée de bactéries $\left(2.10^{6}\right.$ U.F.C./ml) pour n'obtenir qu'environ 0,8 de taux de réussite.

Les plants témoins inoculés avec de l'eau stérile restent sans symptômes. 

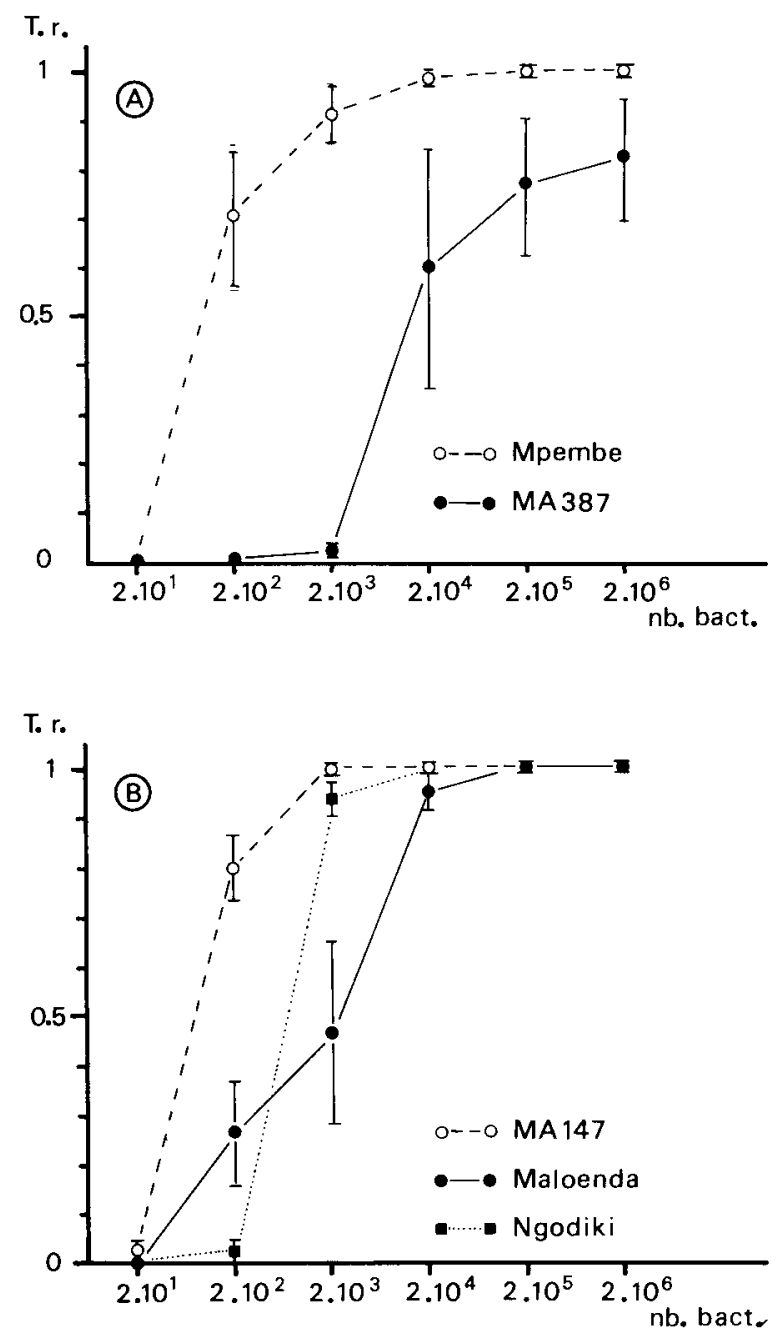

Figure 1

Variation du taux de réussite de l'infection au niveau de trous circulaires de 1,2 mm pratiqués dans le limbe de 5 cultivars de manioc en fonction du nombre de bactéries présentes dans la suspension d'inoculation.

T. r. : taux de réussite, rapport entre le nombre de points d'inoculation présentant des symptômes (taches angulaires) après une semaine d'incubation et le nombre total d'inoculations réalisées. Moyenne de 5 répétitions (30 blessures par répétition). Intervalle de confiance donné pour un risque de 5 p. 100.

$N b$. bact. : nombre de bactéries dans la goutte d'inoculation.

Effect of the number of bacteria in the inoculum suspension on the infection rate in 5 cassava cultivars; inoculation is performed through circular holes, $1.2 \mathrm{~mm}$ in diameter.

$T$. $r$. : rate of success, ratio of number of inoculation sites showing angular leaf spots after one week of incubation and total number of inoculations. Mean of 5 replicates (30 wounds per replicate) and $95 \%$ confidence interval.

$N b$. bact. : number of bacteria in the inoculation drop.

\section{B. Durée de réceptivité de la blessure sur le limbe}

Pour cette expérience, l'inoculum contient $10^{5}$ à $10^{6}$ bactéries par goutte de $0,005 \mathrm{ml}$. L'inoculation faite sur des feuilles de niveaux 3-4 immédiatement après blessure donne des taux de réussite voisins de 1 pour les 6 cultivars testés (tabl. 1, inoculation à To). Si on laisse s'écouler un temps variable entre la lésion et l'inoculation, une baisse du taux de réussite se manifeste (fig. 2 et fig. 3). Des feuilles d'âge croissant du cultivar "Mpembe " ont été inoculées (fig. 2) et l'on constate que le taux de réussite proche de 1 à To
TABLEAU 1

Résultats des inoculations par une goutte d'eau contenant $10^{5}$ à $10^{6}$ bactéries dans la lumière d'une blessure circulaire de $1,2 \mathrm{~mm}$ de diamètre sur le limbe de 6 cultivars. Les inoculations sont réalisées soit immédiatement après blessure (To), soit après $30 \mathrm{~h}$ d'attente $(T o+30 \mathrm{~h})$. La lecture est faite après $7 j$ d'incubation.

Results of inoculation with a drop of water containing $10^{5}$ to $10^{6}$ bacteria in a circular wound $(1.2 \mathrm{~mm}$ in diameter) on the leaf lamina of 6 cultivars. Inoculations performed either immediately after wounding (To) or 30 hours later. Readings made after 7 days of incubation.

\begin{tabular}{lcccc}
\hline \hline & \multicolumn{2}{c}{ Inoculation à To } & \multicolumn{2}{c}{ Inoculation à To+30 h } \\
\cline { 2 - 3 } \cline { 5 - 6 } Cultivars & Nbre inoc. $\begin{array}{c}\text { Nbre inoc. } \\
\text { réussies }\end{array}$ & Nbre inoc. $\begin{array}{c}\text { Nbre inoc. } \\
\text { réussies }\end{array}$ \\
\hline Maloenda (V.) & 150 & 150 & 150 & 34 \\
Mpembe (V.) & 150 & 150 & 150 & 24 \\
MA 147 (T.) & 150 & 150 & 150 & 17 \\
Ngodiki (T.) & 150 & 150 & 150 & 12 \\
MA 446 (T.) & 150 & 150 & 150 & 7 \\
MA 387 (T.) & 150 & 128 & 150 & 3 \\
\hline \hline
\end{tabular}

Nbre inoc. : nombre total d'inoculations réalisées. Total number of inoculations.

Nbre inoc. réussies: nombre des inoculations ayant provoqué l'apparition de taches angulaires. Number of inoculations giving rise to angular leaf spots.

V. : cultivar vulnérable. Vulnerable cultivar (as identified through field screening).

T. : cultivar tolérant. Tolerant cultivar (as identified through field screening).

pour toutes les feuilles baisse brutalement après $12 \mathrm{~h}$ de cicatrisation pour la feuille 2 , alors que ce résultat n'est obtenu pour les autres feuilles qu'après $48 \mathrm{~h}$. Ce phénomène a été constaté pour les 6 cultivars du tableau 1.

L'histogramme (fig. 3) montre le comportement des feuilles de niveau 3 du cultivar " MA 387 » dans les mêmes conditions. Pour cette variété $24 \mathrm{~h}$ de cicatrisation suffisent pour amener le taux de réussite à 0,2 (au lieu de 0,6 pour « Mpembe » au même moment). Les résultats des inoculations à To après $30 \mathrm{~h}$ de cicatrisation (tabl. 1) indiquent que la cicatrisation diminue plus sensiblement le taux de réussite chez les cultivars tolérants que chez les cultivars vulnérables. Les termes vulnérable et tolérant font référence aux observations faites au champ (évaluation de l'intensité des symptômes dans les conditions naturelles).

\section{Etude de la multiplication de la bactérie dans le mésophylle}

Lors des premières $24 \mathrm{~h}$, le parasite se multiplie rapidement (fig. $4 \mathrm{~A}, \mathrm{~B}, \mathrm{C}, \mathrm{D}, \mathrm{E}, \mathrm{F}$ et G). Cette multiplication est en général égale ou même plus rapide chez les cultivars tolérants que chez les sensibles.

Chez certains tolérants (" MA 147 », " MA 387 » et " MA 446 »), un plateau apparait dans la courbe de croissance entre 24 et $48 \mathrm{~h}$. Il est particulièrement marqué pour «MA 387 » et «MA 147 »; pour ce dernier, il est prolongé de $24 \mathrm{~h}$. Dans le cas de «MA 575 », tolérant et des 3 cultivars vulnérables ce palier est absent. 

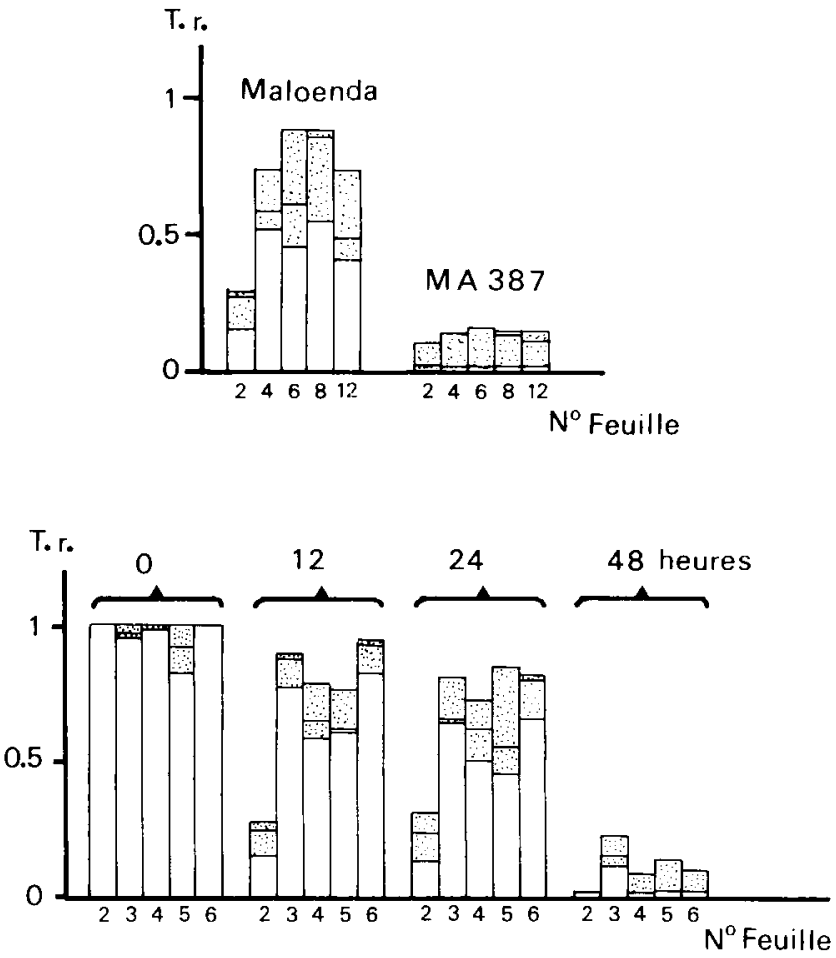

Figure 2

Variation du taux de réussite de l'infection au niveau d'une blessure sur le limbe du cultivar « Mpembe» en fonction de l'âge de la feuille et du temps écoulé entre la réalisation de la blessure et celle de l'inoculation.

T. r. : taux de réussite (voir légende de la fig. 1).

$N^{\circ}$ feuille : numéro indiquant la position de la feuille sur le plant, la feuille 2 est la I $^{r e}$ feuille dont les folioles sont dépliées 3, 4 etc. sont les feuilles suivantes d'âge croissant.

Au-dessus de chaque groupe d'histogrammes est donné le temps séparant la blessure de l'inoculation. Il y a 3 répétitions (30 blessures par répétition). Les 3 résultats sont donnés sur l'histogramme et la partie en pointillé indique la variation entre ces résultats.

Effect of leaf age and time allowed between wounding and inoculation on infection through a wound on cultivar " Mpembe ".

T. $r$. : rate of success (see legend of fig. I).

$N^{\circ}$ feuille : figure giving the position of the leaf on the shoot, leaf 2 is the first with unfolded labes, leaves 3,4 etc. are the following leaves of increasing age. On top of each group of histograms is indicated the time allowed between wounding and inoculation. There are three replicates, with 30 wounds per replicate. The three results are given on the histogram and the dotted space gives the variation between these results.

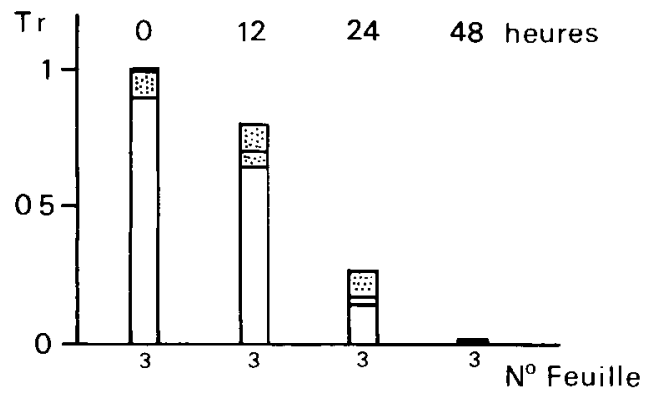

Figure 3

Même légende que pour la fig. 2 mais pour le cultivar «MA 387 "; un seul histogramme est donné correspondant à la feuille de niveau 3.

Same as fig. 2 for cultivar "MA 387 »; the only histogram is for leaf 3.
Pour tous les cultivars, la population du parasite dans les tissus du limbe atteint le même niveau $\left(10^{7}\right.$ U.F.C. $/ \mathrm{cm}^{2}$ de limbe) après $72 \mathrm{~h}$ d'incubation.

L'infiltration de la feuille par une suspension de bactéries sous pression réduite est impossible ou difficile (zones infiltrées de petite taille dont la répartition n'est pas homogène) chez les cultivars de manioc. " MA 446 » se prête mieux que les autres à l'emploi de cette technique et la courbe de croissance du parasite dans les tissus du limbe après infiltration totale a été obtenue (fig. $4 \mathrm{H}$ ). On remarque que la multiplication est plus rapide et le palier moins net qu'après l'inoculation avec blessure.

\section{Invasion de la tige à partir de la feuille inoculée}

La cinétique de la chute des feuilles après inoculation (fig. 5) n'est pas la même pour les 4 cultivars observés. Chez «MA 575 », par exemple, les feuilles tombent avec un retard moyen de $20 \mathrm{j}$ par rapport à «MA 147 » ou « MA 446 ».

Le passage du parasite du limbe de la feuille à la tige, par l'intermédiaire du pétiole, ne se fait pas de la même façon pour les 4 variétés. Le tableau 2 fait apparaître que, au moment de l'abscission, chez "MA 446 » et «Nkoh », la partie proximale du pétiole est atteinte dans la moitié des cas alors que, chez «MA 147 » et «MA 575 », seuls 10 à 15 p. 100 de ces parties sont contaminées. Au même moment on trouve le parasite dans 20 à 30 p. 100 des cicatrices foliaires sur les tiges de "MA 446 » et de «Nkoh» alors qu'il en est absent chez «MA 147» et «MA 575 ». L'analyse de la présence de $X$. c. pv. manihotis dans les tiges en fin d'expérience (tabl. 3) confirme le passage dans le rameau pour «Nkoh » et «MA 446 » et l'absence de passage pour « MA $575 »$. Pour « MA $147 »$, il y a contradiction entre les résultats des tableaux 2 et 3, la bactérie est présente dans 3 des 10 tiges alors que nous ne l'avions détectée dans aucune des cicatrices foliaires prélevées au

TABLEAU 2

Etude de la présence de X. c. pv. manihotis dans la moitié distale du pétiole ( $P$. d.), la moitié proximale $(P . p$.) et la cicatrice foliaire $(C$. f.). Les feuilles inoculées au niveau du limbe de la foliole centrale sont récupérées au moment de leur abscission et analysées par la technique habituelle (désinfection de surface, broyage, incubation dans l'eau, étalement de dilutions de cette eau sur milieu L.P.G.A., vérification de la présence du parasite et de son pouvoir pathogène).

Presence of X. c. $p v$. manihotis in the distal (P. d.), proximal (P. p.) half of the petiole and in the foliar scar of the stem (C. f.). Leaves are infected on the central lobe, collected after leaf fall and analysed following the usual technique (surface sterilization, grinding, incubation in water, plating dilutions of this water on L.P.G.A medium, checking the presence of the parasite and its pathogenicity).

\begin{tabular}{lcccc}
\hline Cultivars & $\begin{array}{c}\text { Nbre feuilles } \\
\text { inoculées }\end{array}$ & $\begin{array}{c}\text { P. d. } \\
\text { contaminées }\end{array}$ & $\begin{array}{c}\text { P. p. } \\
\text { contaminées }\end{array}$ & $\begin{array}{c}\text { C. f. } \\
\text { contaminées }\end{array}$ \\
\hline \hline Nkoh & 50 & 37 & 26 & 11 \\
MA 446 & 40 & 32 & 26 & 15 \\
MA 147 & 49 & 20 & 5 & 0 \\
MA 575 & 49 & 18 & 8 & 0 \\
\hline
\end{tabular}



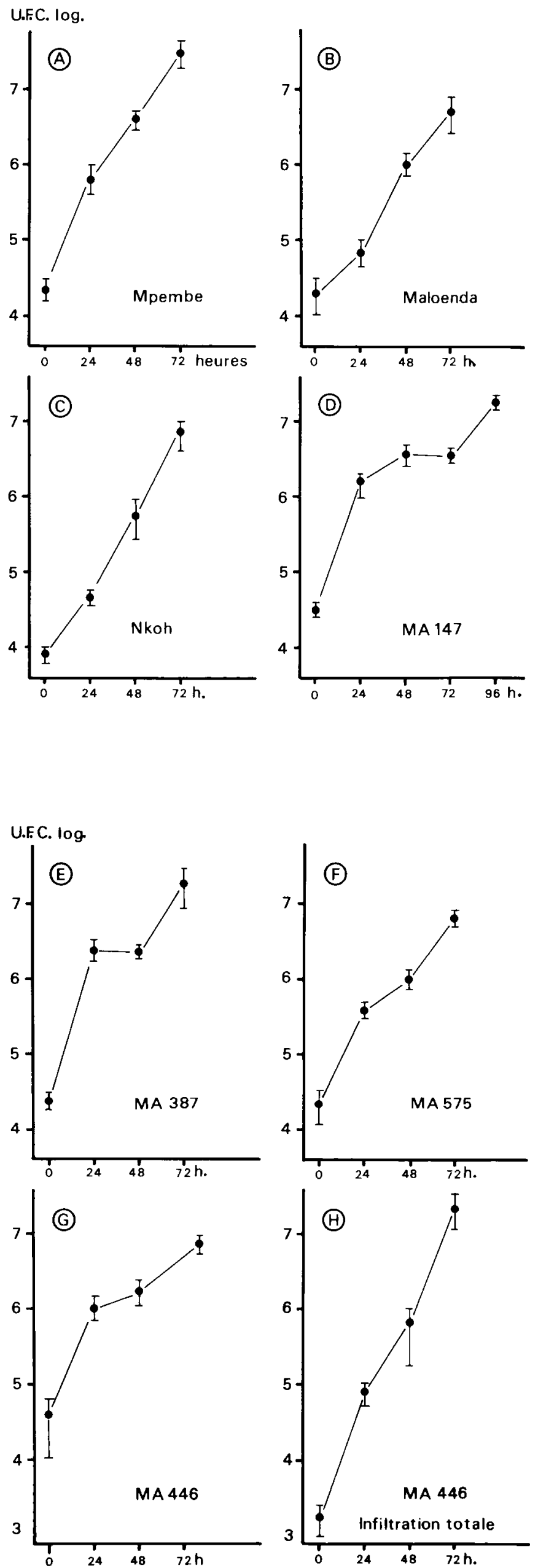

TABLEAU 3

Etude de la présence de X. c. pv. manihotis dans les rameaux ayant porté les feuilles inoculées de l'expérience du tableau 2 ; le ler chiffre indique le nombre de rameaux analysés, le $2^{e}$ le nombre de rameaux contenant le parasite.

Presence of X. c. pv. manihotis in the shoots bearing inoculated leaves in the previous experiment. The first figure refers to the number of analysed shoots, the second to the number of shoots containing the parasite.

\begin{tabular}{ccccc}
\hline \hline Cultivars & Nkoh & MA 446 & MA 147 & MA 575 \\
& $9 / 7$ & $9 / 6$ & $10 / 3$ & $10 / 0$ \\
\hline
\end{tabular}

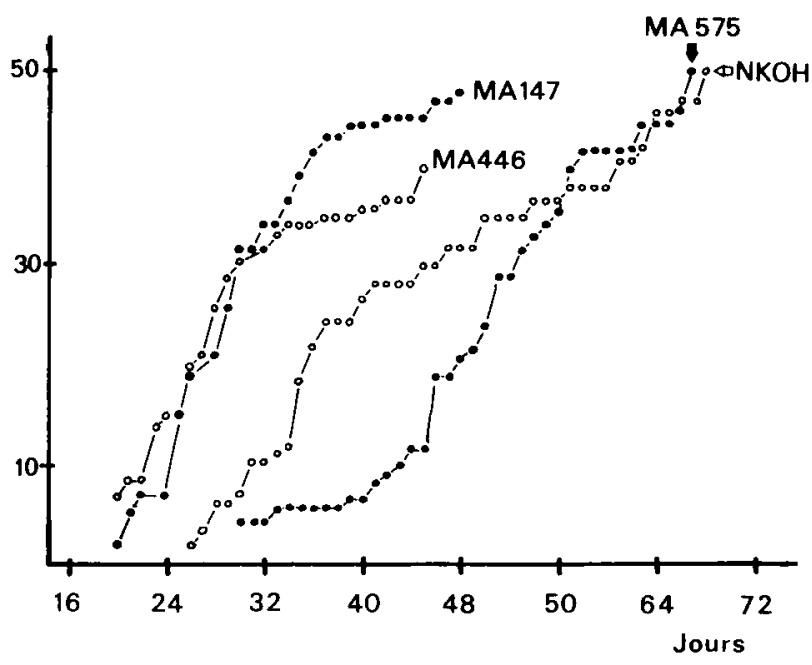

Figure 5

Courbes cumulatives de l'abscission des feuilles chez 4 cultivars de manioc après inoculation du limbe de la foliole centrale par X. c. pv. manihotis. En ordonnée le nombre de feuilles tombées, en abscisse le nombre de jours écoulés depuis l'inoculation.

Cumulative curves of leaf fall in 4 cultivars after the inoculation of the central lobe with $\mathrm{X}$. c. $p v$. manihotis. $y$ axis : number of fallen leaves, $x$ axis : days after inoculation.

Figure 4

Evolution de la population de X. c. pv. manihotis dans le limbe de la feuille de 7 cultivars de manioc au cours du temps (feuilles de niveaux 4 à 6).

L'inoculation est faite par l'infiltration avec blessure (Dermojet) d'une suspension dans l'eau du parasite $\left(10^{8}\right.$ bactéries $\left./ \mathrm{ml}\right)$, sauf dans le cas de la courbe $H$ où il y a eu infiltration totale du limbe sous pression réduite dans la même suspension.

U. F. C. log: logarithme du nombre de colonies obtenues sur milieu nutritif par étalement du broyat de tissus inoculés (nb. de bactéries par point d'inoculation pour $A, B, C, D, E, F, G$, et par $\mathrm{cm}^{2}$ pour $H$ ). Il y a 5 répétitions, l'intervalle de confiance est donné pour un risque de $5 \mathrm{p} .100$.

Fluctuations of X. c. pv. manihotis population in the leaf lamina of 7 cassava cultivars (leaves 4 to 6) at intervals after inoculation.

The inoculation is performed by infiltration through a wound (dermojet) of an aqueous suspension of the parasite $\left(10^{8}\right.$ bacteria $\left./ \mathrm{ml}\right)$, except for curve $H$ where a total infiltration of the lamina is performed under vacuum in the same suspension.

U.F.C. log : log of the number of colonies observed on a nutrient medium after plating the grinding water of inoculated tissues (number of bacteria per inoculation spot for $A, B, C, D, E, F, G$, per $\mathrm{cm}^{2}$ for $H$ ). 5 replicates, $95 \%$ confidence level. 
moment de l'abscission. Ceci peut s'expliquer par le fait que la distribution du parasite dans la tige n'est pas homogène (BOHER \& DANIEL, 1982).

Les réinoculations prouvent que les souches isolées sont virulentes. Les tiges témoins n'ont jamais livré l'agent pathogène à l'isolement.

\section{DISCUSSION}

Le préalable à l'infection des tissus du limbe par $X$. c. pv. manihotis est l'établissement de la phase épiphyte à la surface de la feuille. Lors d'un précédent travail (DANIEL \& BOHER, 1985) nous avons mesuré, dans une région où la maladie est endémique, les niveaux de population du parasite sur le limbe de cultivars vulnérables et tolérants. Il apparaissait que, pendant toute la saison des pluies, ces niveaux étaient élevés ( $10^{6}$ à $10^{7}$ U.F.C. par feuille) et de même ordre, que les cultivars soient vulnérables ou tolérants. Les observations de répliques au collodion de la surface de la feuille après traitement par la technique de l'immunofluorescence indirecte (DANIEL \& BOHER, 1981) ont montré que le parasite était présent sur le limbe sous la forme de petites colonies (moins de 100 bactéries). Les résultats mentionnés ici confirment que de faibles quantités de bactéries peuvent induire l'apparition de symptômes au niveau de blessures.

Cependant, la quantité de germes nécessaires à la réussite de l'infection varie suivant les cultivars. L'élévation du seuil d'inoculum chez certains cultivars contribue sans doute à limiter le nombre de points d'infection sur leurs feuilles dans les conditions naturelles.

La durée de réceptivité des blessures à l'infection est plus ou moins longue suivant les cultivars testés; elle est particulièrement courte chez «MA 387 ». Les blessures apparaissent sur le limbe pendant les tornades quand les feuilles sont malmenées par le vent. Les pluies qui suivent éliminent une bonne partie de la population de l'agent pathogène (DANIEL \& BOHER, 1978) à laquelle il faut 24 à $48 \mathrm{~h}$ pour se reconstituer. Dans ces conditons, chez " MA 387 ", la cicatrisation des blessures a déjà eu lieu et l'infection est peu probable.

Dans la nature, les feuilles jeunes (niveaux $3,4,5$ ) portent souvent moins de taches angulaires que les feuilles plus âgées bien que la population épiphyte du parasite soit homogène. Ce fait peut être en partie expliqué par la faible durée de réceptivité des blessures sur la jeune feuille.

Le plateau entre 24 et $48 \mathrm{~h}$, lors de l'accroissement de la population du parasite chez certains cultivars tolérants, est particulièrement marqué chez «MA 387 » qui, parallèlement, a la plus faible durée de réceptivité au niveau de la blessure. On peut supposer que, chez les cultivars tolérants, les tissus lésés produisent des composés bactériostatiques qui sont absents ou présents en moins grande quantité chez d'autres. La disparition du plateau dans la croissance, lors de l'infiltration sans blessure chez «MA 446 » (fig. 4 G), indique une participation des tissus blessés dans l'inhibition de la croissance de $X$. c. pv. manihotis.

L'impact le plus important de l'agent de la bactériose vasculaire sur la physiologie de l'hôte se situe lors de la colonisation des vaisseaux du xylème de la tige. La lyse des tissus vasculaires et l'obstruction des conduits de la sève brute provoquent le dessèchement des sommités qui peut conduire à la défoliation complète du plant chez certaines variétés vulnérables (« Nkoh », « Mpembe »). D'après LoZANO (comm. pers.), certains cultivars de manioc manifestent une réaction d'hypersensibilité au niveau de la feuille, l'abscission rapide de celle-ci empêchant le parasite d'atteindre la tige. Ce n'est pas le cas pour les cultivars que nous avons observés. Des 2 variétés qui perdent rapidement leurs feuilles malades, l'une présente une forte contamination des tissus de la tige, l'autre une contamination faible. D'autre part, chez le cultivar pour lequel l'abscission est la plus tardive, le passage de la feuille à la tige n'a pas lieu.

Il apparaît certain que, pour un cultivar comme " MA 575 », il y a ralentissement de la migration du parasite dans le xylème de la nervure et du pétiole.

\section{CONCLUSION}

Nos études font ressortir 2 points importants dans l'expression de la tolérance à $X$. $c$. pv. manihotis chez le manioc:

- limitation des possibilités d'infection au niveau de la blessure,

- ralentissement de la migration du parasite dans le système vasculaire.

La prolifération intercellulaire de la bactérie dans le mésophylle lui permet d'atteindre, après $3 \mathrm{j}$, des niveaux de population semblables chez les cultivars étudiés. C'est ce que laissaient prévoir les observations sur terrain (taches angulaires présentes sur tous les cultivars). La réduction du nombre de taches angulaires apparaissant sur les feuilles des cultivars tolérants de manioc a déjà été observée en Amérique du Sud (LOZANO, 1972). Cet auteur suggère l'intervention de la taille de l'ostiole du stomate. Cela reste à vérifier. Nous avons travaillé sur la blessure comme lieu d'infection et mis en évidence 2 caractères préexistants qui peuvent expliquer la limitation du nombre de points d'infection (élévation du seuil d'inoculum, cicatrisation rapide des blessures). Des études cytologiques en cours montrent que à la cicatrisation rapide correspond l'apparition précoce d'un dépôt de callose, composé intervenant dans la résistance à l'infection chez d'autres couples hôte/parasite (PENNAZIO et al., 1981 ; BECKMAN et al., 1982).

C'est le développement intra-vasculaire du parasite qui détermine l'importance des dégâts $X$. c. pv. cassavae Wiehe \& Dowson qui ne colonise pas les vaisseaux (MARAITE \& PerreauX, 1979) n'a qu'une faible incidence sur la physiologie de l'hôte. Chez tous les cultivars que nous avons inoculés, $X . c$. pv. manihotis entre dans le xylème de la feuille mais la fréquence de la migration du parasite des vaisseaux de la feuille à ceux de la tige est variable. Il reste à déterminer par quels mécanismes précis le cultivar tolérant agit sur ces 2 phases du développement parasitaire (abaissement de la fréquence de pénétration dans les trachéides ou/et ralentissement de la migration intravasculaire. C'est ce que nous essayons d'élucider par une étude histologique. 
Le comportement d'un cultivar vis-à-vis de $X . c$. pv. manihotis est une résultante de plusieurs composantes physiologiques qui peuvent agir en sens opposés. Il est probable qu'un seul type de réaction défavorable du parasite puisse conférer à l'hôte un certain degré de tolérance. Cependant, l'orientation de la sélection vers une combinaison de plusieurs barrières anatomo- physiologiques du type de celles mises en évidence ici, bien que difficile, devrait permettre de limiter l'incidence de la bactériose vasculaire sur la production de manioc.

\section{RÉFÉRENCES BIBLIOGRAPHIQUES}

Beckman C. H., Mueller W. C., Tessier B. J., Harrison N. A., 1982. Recognition and callose deposition in response to vascular infection in Fusarium wilt-resistant or susceptible tomato plants. Physiol. Plant Pathol., 20, 1, 1-10.

Boher B., Daniel J. F., 1978. Observations sur les symptômes de maladies présents sur l'appareil aérien de cultivars de manioc en collection au C.R.A.L. de Loudima. Rap. O.R.S.T.O.M., 11 p.

Boher B., Daniel J. F., 1982. Etude de la localisation de Xanthomonas campestris pv. manihotis agent de la bactériose vasculaire dans les tiges de manioc. Rap. O.R.S.T.O.M., $6 \mathrm{p}$.

Crosse J. E., Goodman R. N., Schaffer W. H., 1972. Leaf damage as a predisposing factor in the infection of apple shoots by Erwinia amylovora. Phytopathology, 62, 1, 176-182.

Daft G. C., I eben C., 1972. Bacterial blight of soybeans: epidemiology of blight outbreaks. Phytopathology, 62, 1, 57-62.

Daniel J. F., Boher B., 1978. Epiphytic survival of Xanthomonas manihotis on aerial parts of the cassava plant. 763-771. Proc. 4th Int. Conf. Plant Path. Bact., Angers, I.N.R.A., ed., 979 p.

Daniel J. F., Boher B., 1981. Fluorescent antibody technique for detection of Xanthomonas campestris pv. manihotis on cassava leaves, 176-180. Proc. 5th Int. Conf. Plant Path. Bact., Cali, Lozano J. C. ed., $640 \mathrm{p}$.
Daniel J. F., Boher B., 1985. Epiphytic survival of Xanthomonas campestris pv. manihotis on aerial parts of cassava. Agronomie, 5 (2), 111-115.

Hewitt E. J., 1966. Sand and water culture methods used in the study of plant nutrition. Commonw. Agric. Bureaux, Techn. comm. 22 (2nd edition), $547 \mathrm{p}$.

Krantz A., 1959. L'injecteur sans aiguille Dermojet. Présence médicale, 48, 1807.

Lozano J. C., 1972. Baterial blight of cassava in Colombia : etiology, epidemiology and control Thèse, Univ. Wisc., $114 \mathrm{p}$.

Maraite H., Perreaux D., 1979. Comparative symptom development after infection by Xanthomonas manihotis or $X$. cassavae under controlled conditions, 18-25. In Terry et al. : Cassava Bacterial Blight in Africa, Present and Future. Cent. Overseas Pest Res., Coll. House, Wrights Lane, London W8 5SJ, U.K., 72 p.

Mussel H., 1980. Tolerance to disease, 39-52. In Horsfall A.J. \& Cowling E. B. : Plant Disease Vol. 5, Acad. Press, 534 p.

Pennazio S., Redolfi P., Sapetti C., 1981. Callose formation and permeability changes during the partly localized reaction of Gomphrena globosa to Potato Virus X. Phytopathol. Z., 100, 2, 172-181.

Preece T. F., 1982. The progression of bacterial disease within plants, 71-83. In Rhodes-Roberts M. E. \& Skinner F. A. : « Bacteria and Plants », Acad. Press. 